\title{
Profil Tingkat Berpikir Kreatif Siswa Kelas VII SMP dalam Pemecahan Masalah Pada Pokok Bahasan Segitiga dan Segiempat
}

\author{
Citha Ade Priyandani, Nonik Indrawatiningsih, Ani Afifah
}

\section{(C) 2018 JEMS (Jurnal Edukasi Matematika dan Sains)}

This is an open access article under the CC-BY-SA license (https://creativecommons.org/licenses/bysa/4.0/) ISSN 2337-9049 (print), ISSN 2502-4671 (online)

\begin{abstract}
Abstrak:
Penelitian ini merupakan penelitian kualitatif yang bertujuan untuk mendeskripsikan tingkat berpikir kreatif siswa kelas VII SMP dalam pemecahan masalah pokok bahasan segitiga dan segiempat. Subjek dalam penelitian ini berjumlah 3 siswa dengan kemampuan matematika tinggi, sedang, dan rendah. Pengumpulan data menggunakan tes kemampuan berpikir kreatif, wawancara, dan dokumentasi. Hasil penelitian menunjukkan bahwa subjek berkemampuan matematika tinggi berada pada TBK 4, subjek mampu menunjukkan aspek kelancaran, keluwesan, keaslian, dan keterincian. Subjek berkemampuan matematika sedang berada pada TBK 2, subjek hanya mampu menunjukkan aspek kelancaran dan keluwesan. Sedangkan subjek berkemampuan matematika rendah berada pada TBK 0, subjek tidak mampu menunjukkan semua aspek kemampuan berpikir kreatif.
\end{abstract}

Kata Kunci : Berpikir Kreatif; Tingkat Berpikir Kreatif; Pemecahan Masalah

\begin{abstract}
:
This research is qualitative research that aims to describe the level of creative thinking of Grade VII Middle School students in solving triangles and quadrilateral problems. The subjects in this study were three students with high, medium, and low mathematical abilities. Data collection uses tests of creative thinking skills, interviews, and documentation. The results showed that subjects with high mathematical abilities were at TBK 4, subjects were able to show aspects of fluency, flexibility, authenticity, and detail. Subjects with mathematical abilities are at TBK 2; subjects are only able to show aspects of fluency and flexibility. While subjects with low mathematical ability are at TBK 0 , subjects are not able to show all aspects of creative thinking abilities.
\end{abstract}

Keywords : Creative Thinking; Level of Creative Thinking; Problem Solving

\section{Pendahuluan}

Kemampuan berpikir kreatif siswa dalam matematika maupun dalam bidang lainnya merupakan bagian keterampilan berpikir yang perlu dikembangkan, terutama dalam menghadapi tantangan di era globalisasi. Menurut Siswono (2007) berpikir kreatif merupakan suatu proses yang digunakan ketika seseorang mendatangkan/ memunculkan suatu ide baru. Krulik (dalam Priyanto, 2016) mengatakan bahwa berpikir kreatif termasuk dalam kemampuan berpikir tingkat tinggi yang ditandai dengan kemampuan menyelesaikan masalah dengan cara yang baru, unik, dan berbeda-beda.

Berpikir kreatif seseorang dapat diukur dengan beberapa indikator. Silver (dalam Richardo, 2014) menyebutkan bahwa berpikir kreatif memiliki tiga indikator, diantaranya adalah

Citha Ade Priyandani, STKIP PGRI Pasuruan

adecitha@gmail.com

Nonik Indrawatiningsih, STKIP PGRI Pasuruan

nonikPhy.D@gmail.com

Ani Afifah, STKIP PGRI Pasuruan

fifa.ani@gmail.com 
kelancaran (fluency), keluwesan (flexibility), dan kebaruan (novelty). Filsaime (dalam Fauziah, 2011) memiliki pendapat lain tentang indikator berpikir kreatif. Ia mengatakan bahwa berpikir kreatif memiliki empat aspek, yaitu: 1) kelancaran (fluency) merupakan kemampuan siswa dalam menyatakan beragam ide, beragam jawaban dari suatu permasalahan secara lancar dengan benar dan jelas, 2) keluwesan (flexibility) merupakan kemampuan siswa dalam menyelesaikan masalah dengan strategi yang beragam dan tidak monoton dengan melihat masalah dari sudut pandang yang berbeda-beda, 3) keaslian (originality), merupakan kemampuan siswa dalam menghasilkan ide-ide baru yang tidak biasa dan unik untuk memecahkan suatu permasalahan berdasarkan hasil pemikirannya sendiri, 4) keterincian (elaboration) merupakan kemampuan siswa dalam memperinci dengan detail suatu ide secara runtut dari suatu pemecahan masalah sehingga menjadi lebih menarik. Keempat komponen tersebut meninjau hal yang berbeda dan saling berdiri sendiri, sehingga siswa dengan kemampuan dan latar belakang yang berbeda akan memiliki tingkat berpikir yang berbeda pula.

Tingkat berpikir kreatif seseorang dapat dipandang sebagai serangkaian yang dimulai dari tingkat terendah sampai dengan tingkat tertinggi. Siswono (2007) dalam penelitiannya menjelaskan bahwa tingkat berpikir kreatif memiliki lima tingkatan, yaitu tingkat 4 (sangat kreatif), tingkat 3 (kreatif), tingkat 2 (cukup kreatif), tingkat 1 (kurang kreatif), dan tingkat 0 (tidak kreatif). Siswa yang berada pada tingkat berpikir kreatif tinggi mampu memecahkan msalah dengan lancar, benar, dan jelas. Sedangkan siswa pada tingkat berpikir rendah akan mengalami kesulitan dalam menyelesaikan suatu permasalah bahkan tidak mampu untuk menyelesaikannya.

Berpikir kreatif seringkali dikaitkan dengan pemecahan masalah. Menurut Polya (dalam Aziz, 2014) pemecahan masalah merupakan usaha mencari jalan keluar dari suatu kesulitan untuk mencapai suatu tujuan yang tidak segera dapat dicapai. Siswono (2007) dalam penelitiannya menjelaskan bahwa pemecahan masalah dapat meningkatkan kemampuan berpikir kreatif siswa dalam belajar matematika. Menurut Polya (dalam Sunarya, 2013) pemecahan masalah terdiri dari empat langkah, yaitu memahami masalah, membuat rencana penyelesaian, melaksanakan rencana penyelesaian, memeriksa kembali.

Berdasarkan hasil wawancara peneliti dengan salah satu guru SMP matematika, diperoleh informasi bahwa siswa memiliki kemampuan berpikir kreatif yang berbeda-beda. Hal ini terlihat pada hasil pekerjaan siswa dalam pemecahan masalah. Ada siswa yang menyelesaikan masalah menggunakan caranya sendiri. Namun, ada pula siswa yang hanya menyelesaikan masalah sesuai dengan cara yang telah dicontohkan oleh guru.

\section{Metode}

Jenis penelitian ini adalah penelitian deskriptif kualitatif. Penelitian ini dilaksanakan di salah satu SMP Negeri di Kabupaten Pasuruan. Pemilihan subjek penelitian didasarkan pada hasil tes kemampuan awal siswa. Subjek penelitian terdiri dari 1 subjek kelas VII SMP dengan kemampuan matematika tinggi. Pemilihan subjek dengan kemampuan matematika tinggi diharapkan mampu memberikan informasi lebih detail tentang kemampuan berpikir kreatif siswa.

Teknik pengumpulan data pada penelitian ini adalah tes, wawancara, dan dokumentasi. Instrumen dalam penelitian ini adalah tes kemampuan berpikir kreatif siswa dalam bentuk soal uraian pada pokok bahasan segitiga dan segiempat yang ditelah divalidasi. Berikut adalah instrumen tes kemampuan berpikir kreatif yang digunakan dalam penelitian ini: 
1. Masih ingatkah kalian tentang bangun datar segitiga, segiempat dan macamnya?

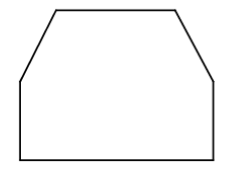

Gambarlah beberapa bangun datar segitiga dan segiempat yang dapat membentuk bangun datar di atas!

\section{Gambar 1. Soal Tes Kemampuan Berpikir Kreatif No. 1}

Soal tes berpikir kreatif siswa nomor 1 diadopsi dari Rahmawati (2016). Soal ini memuat indikator berpikir kreatif, yaitu kelancaran (fluency). Dalam masalah yang tersaji dalam soal nomor 1 ini, siswa diharapkan mampu mengemukakan idenya dengan lancar dan menyelesaikan dengan berbagai macam jawaban benar.

2. Buatlah bangun datar yang berbeda-beda dengan titik sudutnya dari titik-titik

berikut dan luasnya 4 satuan serta setiap titik hanya dapat digunakan sekali!

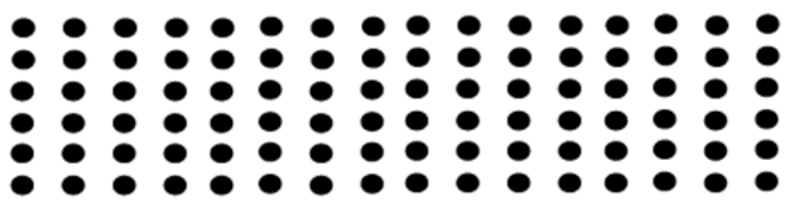

Gambar 2. Soal Tes Kemampuan Berpikir Kreatif No. 2

Soal tes berpikir kreatif siswa nomor 2 diadopsi dari Triyono (2015). Soal ini memuat indikator berpikir kreatif, yaitu kelancaran (fluency) dan keaslian (originality). Dalam masalah yang tersaji dalam soal nomor 2 ini siswa diharapkan mampu mengemukakan idenya dengan lancar dan menyelesaikan dengan berbagai macam jawaban benar serta mampu membuat jawaban lain yang unik dan berbeda dari yang biasa dilakukan siswa pada umumnya.

3. Perhatikan gambar berikut!

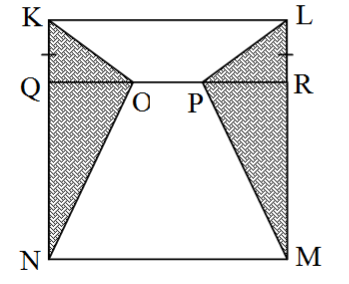

Bangun KLMN di samping merupakan

persegi dengan panjang sisi $21 \mathrm{~cm}$.

Jika $\overline{K Q}=\overline{Q O}=\overline{O P}=\overline{P R}=1 / 3 \overline{K N}$.

Hitunglah luas bangun yang diarsir!

Gambar 3. Soal Tes Kemampuan Berpikir Kreatif No. 3

Soal tes berpikir kreatif siswa nomor 3 diadopsi dari Cahyanti (2017). Soal ini memuat indikator berpikir kreatif, yaitu keluwesan (flexibility), keaslian (originality), dan keterincian (elaboration). Dalam masalah yang tersaji dalam soal nomor 3 ini siswa diharapkan mampu memberikan macam-macam strategi dalam pemecahan masalah, mampu membuat jawaban lain yang unik dan berbeda dari yang biasa dilakukan siswa pada umumnya, dan mampu memperinci secara detail dan runtut dari suatu pemecahan masalah sehingga menjadi lebih menarik. Analisis data yang digunakan dalam penelitian ini berdasarkan analisis data menurut 
Miles dan Huberman (dalam Huda, 2017) yaitu reduksi data, penyajian data, dan penarikan kesimpulan.

\section{Hasil dan Pembahasan}

Pengambilan data dalam penelitian ini dilakukan pada beberapa siswa kelas VII SMP berdasarkan tingkat kemampuan matematika siswa dengan memberikan tes kemampuan awal siswa. Berikut ini akan dideskripsikan dan dipaparkan data penelitian dari subjek yang terpilih, yaitu subjek dengan kemampuan matematika tinggi. Selanjutnya data tersebut diuraikan berdasarkan tahapan pemecahan masalah menurut Polya serta komponen kunci kemampuan berpikir kreatif yang meliputi kelancaran (fluency), keluwesan (flexibility), keaslian (originality), dan keterincian (eleboration). Adapun hasil pengerjaan tes kemampuan berpikir kreatif dan wawancara subjek penelitian dipaparkan sebagai berikut:

1. Subjek dengan Kemampuan Matematika Tinggi dalam Pemecahan Masalah Nomor 1 $\left(S_{1}\right)$

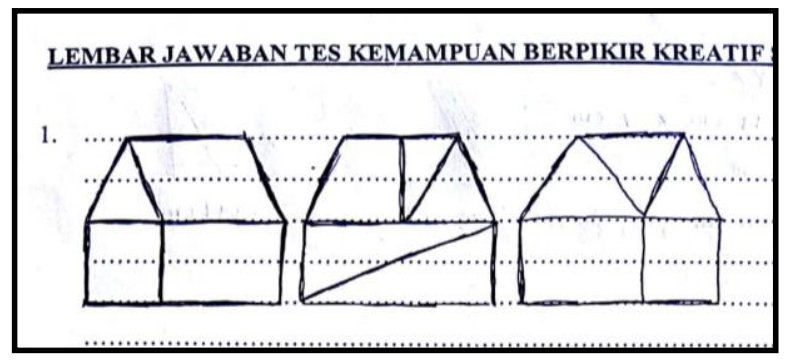

Gambar 4. Jawaban Subjek dalam Pemecahan Masalah No. 1

Berdasarkan gambar 4, dapat dilihat bahwa subjek $S_{1}$ mampu menerapkan pengetahuan yang didapat sebelumnya dengan baik. Subjek $S_{1}$ mampu memahami masalah dengan lancar terbukti dari hasil pekerjaan tes kemampuan berpikir kreatif, subjek $S_{1}$ mampu menyelesaikan masalah no. 1 dengan berbagai macam jawaban benar. Untuk memperoleh informasi lebih lanjut, peneliti melakukan wawancara dengan $S_{1}$. Adapun kutipan wawancara peneliti dengan $S_{1}$ adalah sebagai berikut:

$P \quad$ : "Dari berbagai macam jawaban yang sudah kamu buat, coba

sebutkan satu persatu bangun datar apa saja yang kamu buat supaya

jadi bangun seperti soal ini (soal no. 1)!

$S_{1} \quad$ : "Gambar pertama saya buat seperti rumah bu, ada segitiga,

jajargenjang, dan persegi pnjang. Terus gambar kedua ada

trapesium, dan segitiga, dan gambar ketiga ada segitiga dan persegi

panjang."

$P \quad$ : "Selain bangun datar yang sudah kamu sebutkan tadi, apakah ada bangun datar lain yang bisa digunakan?"

$S_{1} \quad$ : (berpikir) "Oh ada bu. Belah ketupat kayaknya bisa."

$P \quad:$ :Coba gambarkan!"

$S_{1} \quad$ : (mengambil kertas dan mulai mengerjakan). 


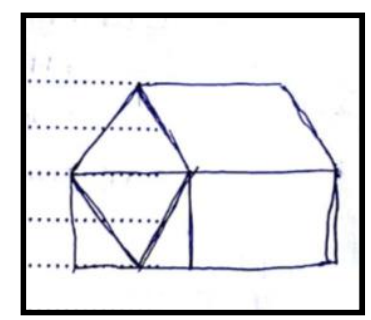

Gambar 5. Jawaban Subjek dalam Pemecahan Masalah No. 1

$P \quad$ : "Coba sebutkan bangun datar apa saja yang sudah kamu buat!"

$S_{1} \quad$ : "Ada belah ketupat, jajargenjang, segitiga siku-siku sama persegi panjang."

$P \quad:$ :Ada lagi?"

$S_{1} \quad$ : "Tidak ada bu."

Berdasarkan hasil wawancara di atas, dapat diketahui bahwa subjek $S_{1}$ mampu melalui tahap kelancaran (fluency) dengan baik. Hal tersebut terlihat dari cara subjek $S_{1}$ mampu menyebutkan lebih dari satu ide untuk menyelesaikan soal nomor 1 dengan benar meskipun ada sedikit keraguan, akan tetapi dari jawaban secara tertulis sudah benar.

Dari hasil tes tulis dan hasil wawancara dapat diketahui bahwa subjek $S_{1}$ dapat mengemukakan idenya dan menyelesaikan soal dengan berbagai macam jawaban benar. Kemudian pada saat wawancara Subjek $S_{1}$ mampu menjelaskan jawabannya dengan lancar dan benar. Hal ini menunjukkan bahwa subjek $S_{1}$ sudah memenuhi salah satu aspek kemampuan berpikir kreatif yaitu kelancaran (fluency).

2. Subjek dengan Kemampuan Matematika Tinggi dalam Pemecahan Masalah Nomor 2 $\left(\mathrm{S}_{1}\right)$

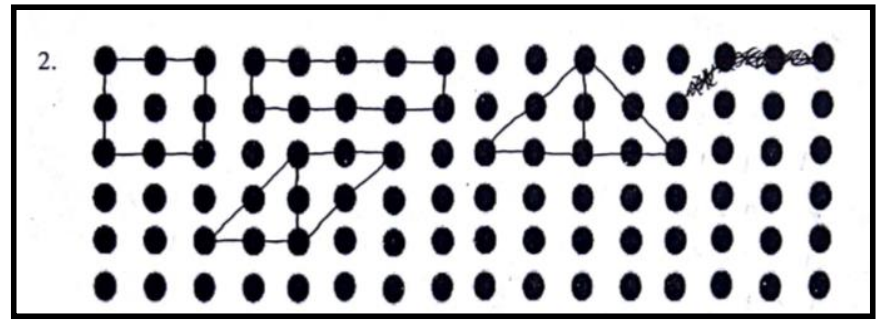

Gambar 6. Jawaban Subjek dalam Pemecahan Masalah No. 2

Berdasarkan hasil tes tulis siswa pada gambar 6 , dapat dilihat bahwa subjek $S_{1}$ mampu memberikan jawaban yang beraneka ragam tentang gambar bangun-bangun datar yang berbeda dengan luas 4 satuan luas. Artinya subjek $S_{1}$ mampu memahami masalah dengan baik, subjek $S_{1}$ dapat menentukan langkah apa saja yang akan digunakan untuk menyelesaikan masalah, subjek $S_{1}$ juga dapat melaksanakan rencana yang dibuat dengan benar dan tepat. Untuk memperoleh informasi lebih lanjut, peneliti melakukan wawancara dengan $S_{1}$. Adapun kutipan wawancara peneliti dengan $S_{1}$ adalah sebagai berikut:

$P \quad$ : "Informasi apa saja yang kamu ketahui dari soal nomor 2?"

$S_{1} \quad$ : "Luas bangun datar yang diminta yaitu 4 satuan luas."

$P \quad$ : "Cara apa yang kamu pikirkan untuk memecahkan masalah ini?"

$S_{1} \quad$ : "Caranya dengan mencari sisi-sisi bangun datarnya, kan luasnya 
sudah diketahui bu."

$P \quad:$ :Coba tuliskan caranya kemudian jelaskan!"

$S_{1} \quad$ : (Subjek $S_{1}$ menuliskan cara penyelesaian soal nomor 2)
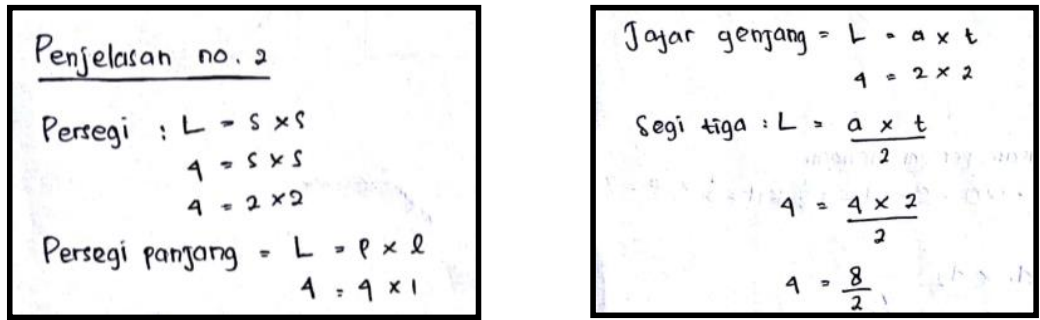

Gambar 7. Jawaban Subjek dalam Pemecahan Masalah No. 2

P : : "Ada tidak bangun datar lain yang luasnya sama selain bangun datar yang sudah kamu buat itu?"

$S_{1} \quad$ : "Sepertinya tidak ada bu."

Berdasarkan hasil wawancara di atas, dapat diketahui bahwa subjek $\mathrm{S}_{1}$ dapat menunjukkan aspek kelancaran (fluency), subjek $S_{1}$ mampu memberikan jawaban yang beragam dan benar. Subjek $S_{1}$ mampu menjelaskan cara yang digunakan dalam pemecahan masalah soal nomor 2 dengan tepat dan lancar. Namun, subjek $S_{1}$ tidak dapat membuat bangun datar lain dengan luas yang sama.

Dari hasil tes tulis dan hasil wawancara dapat diketahui bahwa subjek $\mathrm{S}_{1}$ dapat mengemukakan idenya dan mampu melaksanakan rencana penyelesaiannya dengan lancar dan benar. Selanjutnya pada saat wawancara subjek $S_{1}$ mampu menjelaskan satu persatu secara runtut cara yang digunakan untuk memecahkan masalah pada soal nomor 2. Namun, pada saat subjek $S_{1}$ diminta untuk menggambarkan bangun datar lain dengan ukuran yang sama, subjek $S_{1}$ tidak mampu membuatnya. Hal ini menunjukkan bahwa subjek $S_{1}$ sudah memenuhi aspek berpikir kreatif yaitu aspek kelancaran (fluency), tetapi belum menunjukkan aspek keaslian (originality).

\section{Subjek dengan Kemampuan Matematika Tinggi dalam Pemecahan Masalah Nomor 3} $\left(\mathrm{S}_{1}\right)$

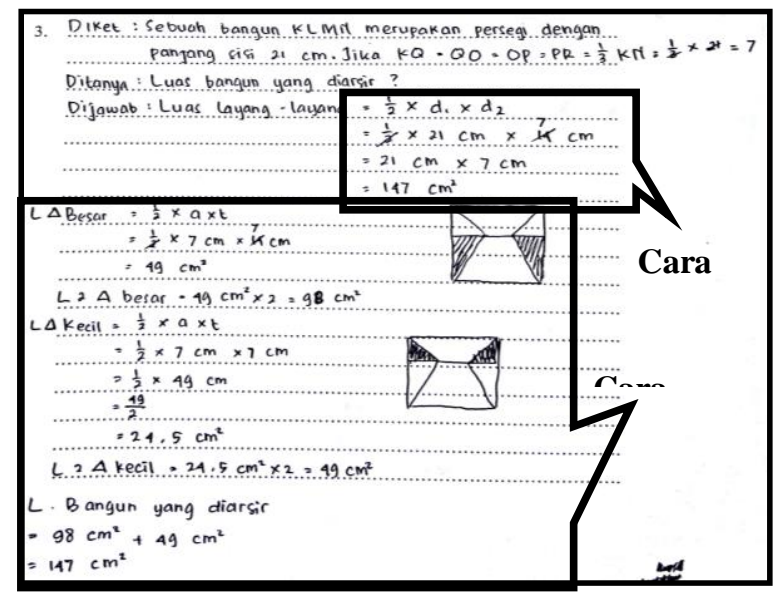

Gambar 8. Jawaban Subjek dalam Pemecahan Masalah No. 3 
Berdasarkan hasil pekerjaan siswa pada gambar 1.8, dapat dilihat bahwa subjek $S_{1}$ mampu memahami masalah yang ada pada soal nomor $3 . S_{1}$ dapat menuliskan informasi yang didapat, seperti apa yang diketahui dan apa yang ditanyakan dari soal nomor 3 . Subjek $S_{1}$ mampu membuat rencana penyelesaian serta melaksanakan rencana penyelesaian dengan tepat dan lancar. Selain itu, subjek $S_{1}$ juga mampu memecahkan masalah dengan banyak cara. Untuk memperoleh informasi lebih lanjut, peneliti melakukan wawancara dengan $\mathrm{S}_{1}$. Adapun kutipan wawancara peneliti dengan $S_{1}$ adalah sebagai berikut:

$P \quad$ : "Informasi apa saja yang dapat kamu ketahui dari soal nomor 3?"

$S_{1} \quad$ : "Panjang sisi persegi KLMN sama dengan $21 \mathrm{~cm}$, panjang

$K Q=Q O=O P=P R=L R=1 / 3 \mathrm{KN}$.

Jadi panjang $K Q=\frac{1}{3} \times 21 \mathrm{~cm}=7 \mathrm{~cm}$.

$P \quad$ : "Strategi apa yang kamu gunakan untuk memecahkan masalah nomor 3?"

$S_{1} \quad$ : "Ada 2 cara bu. Cara pertama pakai rumus luas layang-layang, yang dicari kan luas daerah arsiran, kalau gambar arsirannya dipotong dan dijadikan satu bisa jadi betuk layang-layang. Kemudian cara yang kedua pakai rumus segitiga, kalau dipotong-potong gambarnya kan ada jadi ada 2 segitiga arsiran kecil dan segitiga arsiran besar, tinggal dicari luasnya terus dijumlah."

$P \quad$ : "Apakah cara yang kamu gunakan untuk memecahkan masalah nomor 3 sudah tepat?"

$S_{1} \quad$ : "Sudah bu."

$P \quad: \quad$ :Apa ada cara lain selain 2 cara tadi?"

$S_{1} \quad$ : (berpikir sambil memperhatikan gambar pada soal nomor 3 ).

$P \quad$ : "Bagaimana, ada cara lain?"

$S_{1} \quad$ : "Adabu."

$P \quad:$ :Coba kerjakan!"

$S_{1} \quad$ : (menyelesaikan masalah nomor 3 dengan cara yang berbeda).

"Hampir sama kayak cara 2 bu, tapi kalau ini dua segitiga kecilnya dipotong terus dijadikan satu bisa jadi persegi dengan panjang sisinya $7 \mathrm{~cm}$. Terus 2 segitiga besarnya dipotong juga dijadikan satu membentuk persegi panjang, lebarnya $7 \mathrm{~cm}$ dan panjangnya $14 \mathrm{~cm}$.

Jadi luas bangun arsiran sama dengan luas persegi ditambah luas persegi panjang."

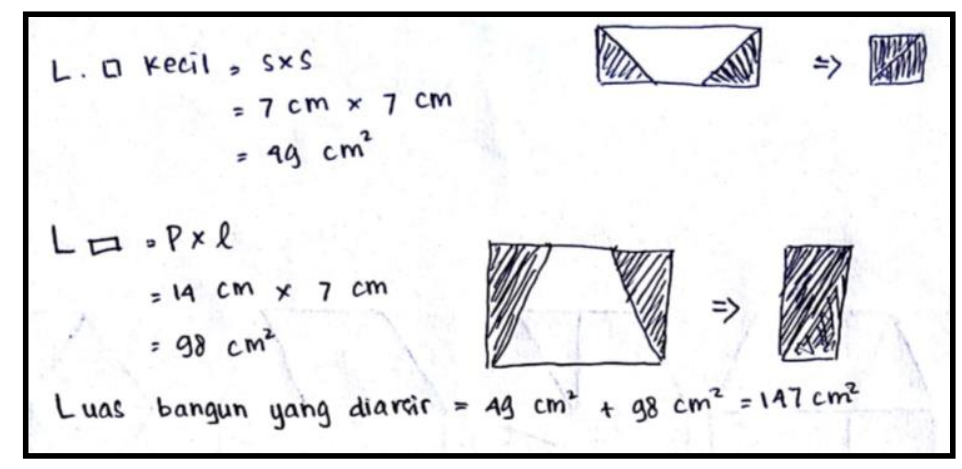

Gambar 9. Jawaban Subjek dalam Pemecahan Masalah No. 3

Berdasarkan cuplikan hasil wawancara di atas, dapat diketahui bahwa subjek $\mathrm{S}_{1}$ mampu membuat rencana penyelesaian masalah dari informasi yang didapat dengan baik dan lancar. Subjek $S_{1}$ mampu melaksanakan rencana penyelesaian dengan tepat dan benar. Selain itu subjek 
$\mathrm{S}_{1}$ dapat menyelesaikan masalah nomor 3 dengan berbagai macam strategi penyelesaian dengan benar dan lancar.

Dari hasil tes tulis dan hasil wawancara, dapat diketahui bahwa subjek $\mathrm{S}_{1}$ mampu menunjukkan tiga aspek kemampuan berpikir kreatif, yaitu keluwesan (flexibility), keaslian (originality), dan keterincian (eleboration). Terbukti dari tes tulis yang dikerjakan, subjek $\mathrm{S}_{1}$ mampu memberikan macam-macam cara untuk menyelesaikan soal nomor 3. Subjek $S_{1}$ mampu melihat masalah dari sudut pandang yang berbeda. Subjek $S_{1}$ mampu memecahkan masalah nomor 3 dengan caranya sendiri, cara penyelesaian yang berbeda dari yang biasa dilakukan oleh siswa pada tingkatannya. Subjek $S_{1}$ juga mampu menguraikan jawaban dari pemecahan masalah yang dibuat secara runtut dan benar.

Berdasarkan uraian tersebut di atas, dapat disimpulkan bahwa subjek $S_{1}$ berada pada tingkat berpikir kreatif 4, yaitu sangat kreatif. Terbukti dari hasil tes tulis serta wawancara yang menunjukkan bahwa subjek $S_{1}$ mampu memenuhi keempat indikator kemampuan berpikir kreatif dalam memecahkan masalah, yaitu kelancaran (fluency), keluwesan (flexibility), keaslian (originality), dan keterincian (elaboration). Subjek $S_{1}$ mampu memecahkan masalah lebih dari satu alternatif jawaban dengan lancar dan fleksibel. Subjek $S_{1}$ dapat menyebutkan dan menuliskan apa yang diketahui dan apa yang ditanyakan dengan lancar. Subjek $S_{1}$ mampu membuat rencana pemecahan masalah serta mampu melaksanakan rencana pemecahan masalah dengan lancar dan benar. Selain itu, subjek $S_{1}$ juga mampu dengan mudah memeriksa kembali hasil yang diperoleh dengan memeriksa kembali setiap langkah dan perhitungan yang telah dilakukan.

Berdasarkan beberapa temuan yang telah dipaparkan oleh peneliti, dapat dikatakan bahwa siswa dengan kemampuan matematika yang berbeda memiliki kemampuan berpikir kreatif yang berbeda dan terdapat perbedaan kemampuan berpikir kreatif siswa pada setiap tingkatan. Hal ini sejalan dengan penelitian yang dilakukan oleh Siswono dan Budayasa (2006) yang menjelaskan bahwa karakteristik proses berpikir kreatif untuk siswa yang menempati tingkat tertinggi (TBK 4) berbeda dengan siswa yang berada pada tingkat dibawahnya. Penelitian yang dilakukan oleh Wulantina (2015) juga menjelaskan hal yang sama, yaitu terdapat perbedaan proses berpikir kreatif siswa antara siswa dengan kemampuan matematika tinggi, sedang, dan rendah. Hasil penelitian menunjukkan bahwa siswa pada tingkat kemampuan matematika rendah kurang cermat dalam mengambil kesimpulan sehingga terdapat kesalahan pada jawaban akhir. Siswa tidak memilih cara yang paling benar karena ia hanya menemukan satu ide penyelesaian. Sedangkan siswa pada tingkat kemampuan matematika tinggi mampu menyelesaikan masalah dengan cermat sehingga hasil akhir dari jawaban pemecahan masalah benar dan tepat. Dengan demikian, jelas bahwa terdapat perbedaan kemampuan berpikir kreatif antara siswa dengan kemampuan matematika tinggi, sedang dan rendah.

\section{Simpulan}

Berdasarkan hasil penelitian dan pembahasan yang telah dipaparkan, maka diperoleh kesimpulan bahwa subjek dengan kemampuan matematika tinggi berada pada tingkat berpikir kreatif (TBK) 4, yaitu sangat kreatif. Subjek dalam pemecahan masalah mampu mencapai empat aspek berpikir kreatif yaitu kelancaran (fluency), keluwesan (flexibility), keaslian (originality) dan keterincian (elaboration).

Beberapa saran yang dapat diberikan peneliti adalah sebagai berikut: (1) siswa hendaknya lebih banyak mengasah kemampuan berpikir kreatif dengan cara menyelesaikan soal-soal berbasis pemecahan masalah. Sehingga kemampuan berpikir kreatifnya semakin meningkat; (2) sebaiknya guru mengetahui kemampuan berpikir kreatif siswa dalam menyelesaikan masalah 
matematika, sehingga dapat menentukan metode pembelajaran yang efektif. Selain itu, sebaiknya guru lebih sering memberikan latihan soal berbasis pemecahan masalah agar siswa mampu mengembangkan kemampuan berpikir kreatifnya; (3) perlu dilakukan penelitian lanjutan untuk mengetahui karakteristik kemampuan berpikir kreatif pada tingkat berpikir kreatif (TBK) lainnya.

\section{Daftar Rujukan}

Aziz, Abdul. 2014. Proses Berpikir Kreatif dalam Pemecahan Masalah Matematika Ditinjau dari Tipe Kepribadian Dimensi Myer-Briggs Siswa Kelas VIII MTs NW Suralaga Lombok Timur Tahun Pelajaran 2013/2014. Jurnal Elektronik Pembelajaran Matematika. 2(10)

Cahyanti, Laellina. 2017. Analisis Kemampuan Berpikir Kreatif Matematis Ditinjau dari Kerja Keras Siswa Kelas VII A Pondok Pesantren Modern Zam-zam Cilongkok. Skripsi tidak diterbitkan. Purwokerto: Universitas Muhammadiyah Purwokerto.

Fauziah, Yuli Nurul. 2011. Analisis Kemampuan Guru dalam Mengembangkan Keterampilan Berpikir Kreatif Siswa Sekolah Dasar Kelas V pada Pembelajaran IPA. Jurnal Edisi Khusus. (2).

Huda, Nurul. 2017. Profil Berpikir Kreatif Siswa dalam Memecahkn Masalah Segitiga Berdasarkan Tingkat Kemampuan Matematis Kelas VII SMP Negeri 1 Palu. Jurnal Elektronik Pendidikan Matematika Tadulako. 4(3): 382-396.

Prianto, Agus. 2016. Berpikir Kreatif dalam Pembelajaran RME. Jurnal Pendidikan. 1(7): 14421448.

Rahmawati, Irna. 2016. Analisis Kemampuan Berpikir Kreatif Matematis Siswa SMP. Skripsi tidak diterbitkan. Jakarta: Universitas Islam Negeri Syarif Hidayatullah Jakarta.

Richardo, Rino. 2014. Tingkat Kreativitas Siswa dalam Memecahkan Masalah Matematika Divergen Ditinjau dari Gaya Belajar Siswa. Jurnal Elektronik Pembelajaran Matematika. 2(2).

Siswono, T.Y.E. \& I.K, Budayasa. 2006. Implementasi Teori Tentang Tingkat Berpikir Kreatif dalam Matematika. Makalah disajikan dalam Seminar Konferensi Nasional Matematika XIII dan Kongres Himpunan Matematika Indonesia di Universitas Negeri Semarang, Semarang, 24-27 Juli.

Siswono, T.Y.E. 2007a. Konstruksi Teoritik Tentang Tingkat Berpikir Kreatif Siswa dalam Matematika. Jurnal Pendidikan, Forum Pendidikan dan Ilmu Pengetahuan. 2(4).

Siwono, T.Y.E. 2007b. Meningkatkan Kemampuan Berpikir Kreatif Siswa Melalui Pengajuan Masalah dan Pemecahan Masalah Matematika. Makalah disampaikan pada Simposium Nasional Penelitian Pendidikan di Pusat Studi Kebijakan Departemen Pendidikan Nasional, Jakarta, 25-26 Juli. 
Sunarya, Linda. 2013. Profil Tingkat Berpikir Kreatif Siswa Kelas VII SMP Negeri 16 Surakarta dalam Pemecahan Masalah Aritmatika Sosial Ditinjau dari Motivasi dan Gender. Jurnal Elektronik Pembelajaran Matematika. 1(7).

Triyono, Fajar. 2015. Analisis Proses Berpikir Kreatif Siswa dalam Pemecahan Masalah Open Ended dengan Model Empat-K Materi Segitiga dan Segiempat. Skripsi tidak diterbitkan. Semarang: Universitas Negeri Semarang.

Wulantina, Endah. 2015. Proses Berpikir Kreatif Siswa dalam Pemecahan Masalah Matematika Ditinjau dari Kemampuan Matematika pada Siswa Kelas X MIA SMAN 6 Surakarta. Jurnal Elektronik Pembelajaran Matematika. 3(6): 671-682. 